\title{
Prospects and challenges in ginger cultivation: Livelihood of the rural farmers in Dima Hasao district, Assam
}

\author{
Phyllis Haizeutuale Panme* and Lalzo S. Thangjom \\ Department of Social Work, Assam University, Silchar (Assam) India
}

\begin{abstract}
Ginger is an important cash crop which has gained a popular status among other major commercial crops for its profitability. Ginger cultivation provides additional income to households especially for the rural farmers in North Eastern India. The present study is an attempt to explore the prospects and challenges in ginger cultivation with special reference to Dima Hasao district of Assam. The major challenges that affects ginger production and marketing in the area under study is price fluctuation and inconsistent of ginger. Other factors like low innovation specific for ginger cultivation, lack of storage facilities, land tenure system affect the production as well as marketing of ginger. On the other hand the prospect of ginger cultivation is attributed to its profitability with very low investments. Since the cultivation of ginger in the area under study employs traditional method it requires no fertilizers and crop is easily maintained. The climatic condition in Dima Hasao district is ideal for growing ginger so, with the right approach and policy implementation, ginger has the potential to promote livelihood of the poor rural farmers on the district. Ginger cultivation can also be cultivated to provide supplementary additional income along with other crops. Promotion of livelihood in Dima Hasao district in order to secure the livelihood of the people within the traditional framework is a primary concern of the study.
\end{abstract}

Key Words : Ginger production, Livelihood, Shifting cultivation, Marketing issues

View Point Article : Panme, Phyllis Haizeutuale and Thangjom, Lalzo S. (2021). Prospects and challenges in ginger cultivation: Livelihood of the rural farmers in Dima Hasao district, Assam. Internat. J. agric. Sci., 17 (2) : 724-728, DOI:10.15740/HAS/IJAS/17.2/724-728. Copyright@2021: Hind Agri-Horticultural Society.

Article History : Received : 02.03.2021; Accepted : 19.03.2021

\footnotetext{
* Author for correspondence :
} 